\title{
鉄鋼および化学産業におけるフッ素の マテリアルフロー
}

\author{
藤岡＼cjkstart義彰＊・柴田 悦郎*2・葛西 栄輝 $* 2 \cdot$ 中村 崇*2 \\ Material Flow of Fluorine in Steel and Chemical Industries \\ Yoshiaki FujoKa, Etsuo ShiBata, Eiki KaSA and Takashi NaKAmura
}

\begin{abstract}
Synopsis : It is very important to know material flows of various substances for better understanding of the environmental impacts of the substances. The material flow of fluorine in the industrial use and the influence of the environmental regulation were investigated from a total point of view for trying to control the fluorine waste in environment. The waste water-Discharge standards of fluorine based on the law on water pollution prevention was reinforced from $15 \mathrm{mg} / 1$ to $8 \mathrm{mg} / 1$ in 2001 .

Almost $100 \%$ of fluorine was imported and $90 \%$ of it was fluorspar. Main users of fluorine in Japan were the steel industry and the chemical industry and over $90 \%$ of fluorine was consumed in both industries during the period investigated in this study.

The amount of fluorine use in Japan decreased totally after reinforcement of waste water-Discharge standards due to the decrease of the steel industry use. Because most fluorine finally changes to slags as a by-product and they are target of reinforcement. On the other hand, fluoride compounds produced in the chemical industry are valuable products. Only the production of Chlorofluorocarbons was stopped to prevent a destruction of ozone layer. The drain management techniques of waste water containing fluorine were also discussed and a simple concept for the recycling of fluorine was proposed.
\end{abstract}

Key words: material flow; fluorine; waste water-Discharge standards; legal reinforcement of regulation; fluorocarbon; fluorite; the steel industry; the chemical indusutry.

\section{1. 緒言}

地球温暖化，オゾン層破壊，有害物質の拡散など，ここ 十数年で地球環境問題は人類が解決すべき最大の課題の一 つとなってきた。高度な産業社会を形成している先進国で は，生産活動が大きくなり，その結果として生活が豊かに なり，従来の地球の浄化作用を超えた人工的な排出物が生 じ，そのため地球規模で生活環境に影響が見られるように なった。

生活廃棄物も産業廃棄物も地球上に十分なスペースと浄 化作用があるならば，しかるべきところに廃棄するのが経 済的にはもっとも合理性がある。しかしながら最早，産業 活動が活発な地域では, 地球の浄化作用が廃棄物量に対応 できないのは明からであり，また人類は自然には存在しな い人工物を作り出し，それらの多くは地球の自然浄化作用 では浄化できないことが多い。

日本国内では，第二次世界大戦後，産業活動の拡大に努 めてきたが，高度経済成長期に入ったころから次第に従来 型の公害問題が顕在化した。かなりの時間を要したが，一 産業，一企業が発生源となってきた公害問題は，一応の解 決を見ている。現在, 環境問題は, 生活者すべてが被害者
であり，加害者になっている点が特徵的であり，解決策を 見出すことの困難さがそこにある。

現在の課題は持続可能な発展であるが，計画経済の手法 が崩壞した現在, 自由経済の下で産業発展と環境保全を共 進化させることが重要な課題である。現在，人類が使用し ている多くの物質に関して自然循環と人工循環のバランス を知ることは，この共進化を考える上で重要なことと言え る。

鉄鋼業をはじめ各産業においては，フッ素の使用量，排 出規制, 再利用が重要視されており, 蛍石に変わるフラッ クスの導入りやフロンの回収破壊技術および代替物質の開 発 ${ }^{21}$, 排水中への溶出抑制技術 ${ }^{31}$ の開発などが進められて いる。

フッ素の環境中への排出抑制，産業廃亲物中のフッ化物 量の低減および再利用などを効率的に図るためには、フッ 化物の資源の輸入，加工，製造，消費，廃萧にわたるト一 タルな観点から捉えたマテリアルフローを検討することが 重要である。現在までに,このような研究を行っている例 は，1997年の著者らの一部が行った報告以外に見受けら れない4)。そこで，今回はフッ素の規制が新たに導入され た後のフッ素のマテリアルフローを作成し, 法的規制強化 


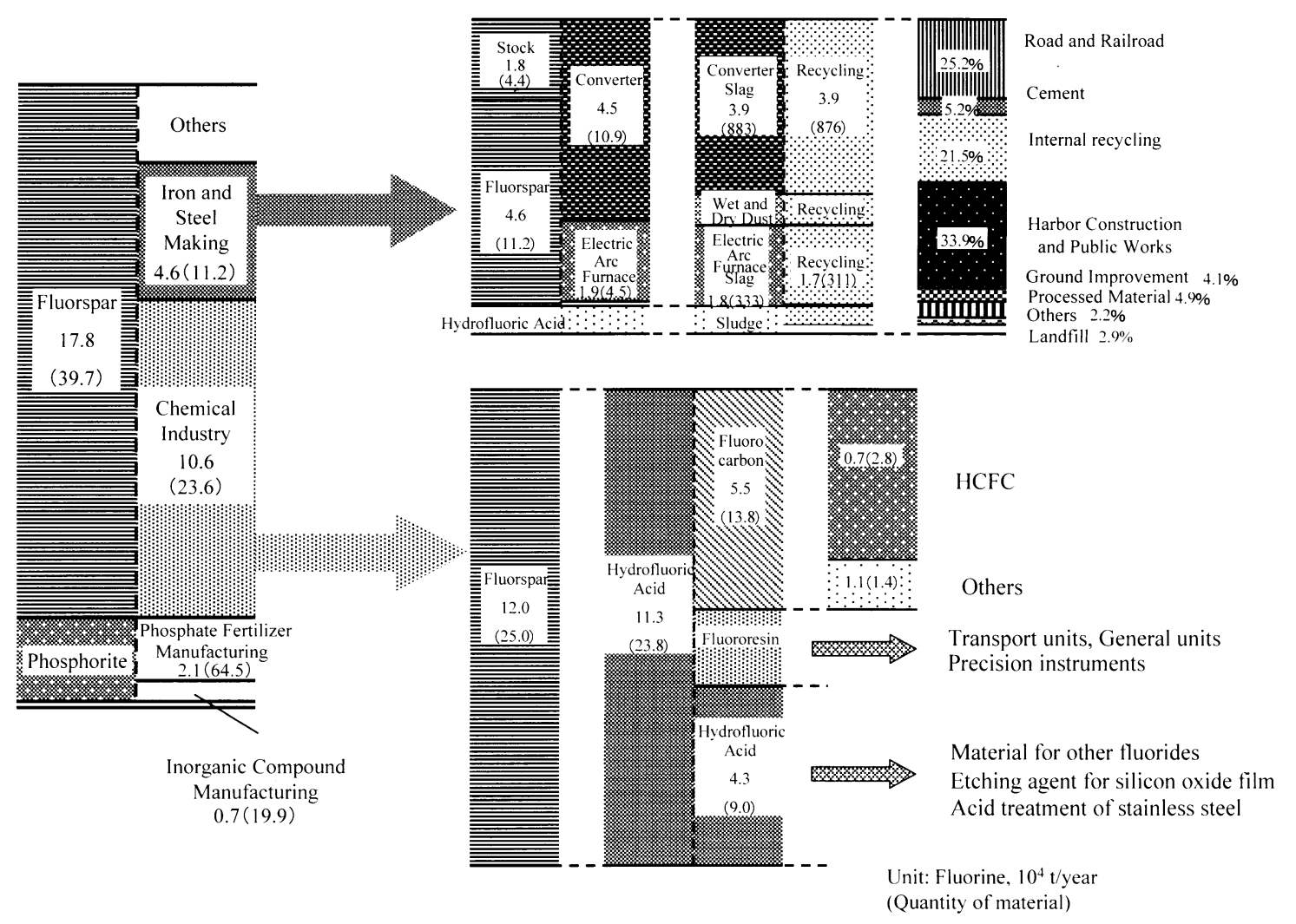

Fig. 1. Material flow diagram of fluorine in Japan (2002).

が産業に与える影響について評価を試みた。

\section{2. フッ素}

多くの元素は，生態にとって必須性と有害性を併せ持っ ている。現在, 環境規制が検討されている亜鉛は, 人間に とって必須元素であることもよく知られている。フッ素は， アパタイトの一部として㐘や骨を強化する作用もあるが， 過剩にあると毒性を示し, 動物実験では, フッ素イオンの 長期陉取によって甲状腺腫が発生し, 発育障害を引き起こ すことや5.6), $8 \mathrm{ppm}$ 以上のフッ素イオンを含有した食物や 飲料を 10 年間掑取し続けると, フッ素中毒症といわれる 骨に結合している筋肉や勒帯にカルシウムが沈着し石灰化 を起こすことが報告されている7”。これらの報告が基とな り，水道法に基づく水質基準はフッ素濃度 $0.8 \mathrm{mg} / \mathrm{L}$, 水質 污濁法に基づくフッ素排水基準は $15 \mathrm{mg} / \mathrm{L}$ であったが, 2001 年より排水基準の規制強化により 15 から $8 \mathrm{mg} / \mathrm{L}$ へと 絾しくなった ${ }^{81}$ 。

現在, 工業的に使用されるほとんどのフッ化物は蛍石を 出発原料としており, 日本には年間約 40 万トン（フッ素 基準では約 18 万トン）が輸入されている。

生産されるフッ化物のほとんどは, 蛍石に硫酸を作用さ せて得られるフッ化水素から合成される。製造されるフッ 化物は一連の化学製品（フッ化ナトリウム, フッ化アンモ ニウムなど）や冷蔵庫の冷媒や半導体の洗浄剂等に使われ
るフロンなどである。また，フッ化水素はフッ化物製造原 料としての他に, めっき, ガラス腐食, 鋳物脱酸などにも 利用されている。

\section{3. 日本におけるフッ素のマテリアルフロー 概要}

日本国内のフッ素源は, 蛍石, 肥料原料となるリン鉱石, フッ化物の化学製品という形で輸入される。Fig. 1 に2002 年のフッ素のマテリアルフロー概観を示す。各量のスケー ルは輸入材に含まれるフッ素量に合わせている。カッコ内 の数值は輸入剂の実量である。フッ素の実量は, 柴田らに よる方法と同じ考え方で算出した4。 フッ素換算で 20 万卜 ンを輸入しているが，その内 $90 \%$ 以上が蛍石の形態で輸 入されている。後述するが, 监石が輸入の中心であること は長年変化がない。輸入先は主に中国である9!。蛍石以外 のフッ素を含有した鉱物資源としてはリン鉱石があり，無 機質源のリン鉱石はりん灰石(Apatite)とよばれ， $\mathrm{Ca}_{5}(\mathrm{~F}, \mathrm{Cl})\left(\mathrm{PO}_{4}\right)_{3}$ の化学成分で表される。リン鉱石の主な産 出国はアメリカおよびモロッコで, 日本国内には主にアメ リカから輸入され, 燐酸肥料, 燐酸などの製造原料として 消費されている9!。

フッ素の主な用途は、鉄鋼製錬用フラックスと化学製品 の原料，種々の洗浄に使用されるフッ化水素であり，2002 年では，化学工業と鉄鋼業で使用される量比が約 $2: 1$ であ 
Table 1. Production amount of steel making slag.

\begin{tabular}{ccccccc}
\hline Year & \multicolumn{2}{c}{1997} & \multicolumn{2}{c}{2001} & \multicolumn{2}{c}{2002} \\
\hline & $\begin{array}{c}\text { Amount } \\
\left(10^{3} \mathrm{t}\right)\end{array}$ & $\begin{array}{c}\text { Ratio } \\
(\mathrm{kg} / \mathrm{t}-\mathrm{s})\end{array}$ & $\begin{array}{c}\text { Amount } \\
\left(10^{3} \mathrm{t}\right)\end{array}$ & $\begin{array}{c}\text { Ratio } \\
(\mathrm{kg} / \mathrm{t}-\mathrm{s})\end{array}$ & $\begin{array}{c}\text { Amount } \\
\left(10^{3} \mathrm{t}\right)\end{array}$ & $\begin{array}{c}\text { Ratio } \\
(\mathrm{kg} / \mathrm{t}-\mathrm{s})\end{array}$ \\
\hline $\begin{array}{c}\text { Converter Slag } \\
10246\end{array}$ & 148 & 10508 & 144 & 8839 & 112 \\
\hline $\begin{array}{c}\text { Electric Arc } \\
\text { Furnace Slag }\end{array}$ & 3963 & 123 & 3214 & 119 & 3329 & 114 \\
\hline
\end{tabular}

*( $\mathrm{kg} / \mathrm{t}$-s $)$ : generation ratio of slag per steel ton

Table 2. Recycling of steel making slag.

\begin{tabular}{ccccccc}
\hline & \multicolumn{2}{c}{ Converter Slag $\left(10^{3} \mathrm{t}\right)$} & \multicolumn{3}{c}{ Electric Arc Furnace Slag $\left(10^{3} \mathrm{t}\right)$} \\
\hline Year & 1997 & 2001 & 2002 & 1997 & 2001 & 2002 \\
\hline Internal recycling & 2018 & 2515 & 1987 & 413 & 207 & 131 \\
\hline Road and Railroad & 840 & 1344 & 1940 & 1221 & 1105 & 1528 \\
\hline $\begin{array}{c}\text { Ground Improvement } \\
\text { Harbor Construction and } \\
\text { Public Works }\end{array}$ & 2325 & 2581 & 4353 & 292 & 541 & 688 \\
\hline Cement & 434 & 611 & 485 & - & 52 & 66 \\
\hline Concrete & - & - & 36 & - & & 0 \\
\hline Processed Material & & - & 381 & 595 & -100 & 298 \\
\hline Other recycling & 996 & 414 & 166 & 160 & 849 & 108 \\
\hline Reclamation & 62 & 118 & 78 & 723 & 223 & 212 \\
\hline Total & 6675 & 7485 & 9890 & 3404 & 3077 & 3153 \\
\hline
\end{tabular}

る。ただ，鉄鋼業で使用したフッ素量は 6.4 万トンであり， これは従来の備蓄（1.8万トン）を取り崩したためである。 蛍石は一貫製鉄所の転炉用と主に特殊鋼を製造する電気炉 用フラックスとして使用されており，そのスラグ生成量の 比は約 $2: 1$ となっている。その他，ステンレス鋼の酸洗用 のフッ酸である。その後のフッ素の流れは後述する。化学 工業では，フッ素化合物の原料として初めにほとんどが フッ酸に変換され，使用される。約その半分がフロン系の 化合物の合成に使用される。

その他の用途は主に，ガラス工業，セメント製造業など に消費されるものと考えられる。リン鉱石と硫酸とを反応 させて, 燐酸肥料や燐酸を製造する過程で発生する四フッ 化ケイ素 $\left(\mathrm{SiF}_{4}\right)$ やフッ化水素 $(\mathrm{HF})$ を含む蒸気は, ケイ フッ化ソーダ $\left(\mathrm{Na}_{2} \mathrm{SiF}_{6}\right)$ や水晶石 $\left(\mathrm{Na}_{3} \mathrm{AlF}_{6}\right)$ の形で回収し， アルミニウム精鍊のフラックスに使用される。

\section{$3 \cdot 1$ 日本の鉄鋼業におけるフッ素のマテリアルフロー}

鉄鋼業においては, フッ素は溶銑予備処理, 転炉, 電気 炉のフラックスとしての使用が中心である。その強い㳯化 作用を生かし脱硫, 脱燐いずれにも利用されている。した がって，その使用後の形態としては，スラグが中心となり， 一部はダストに含まれて排出される。

Table 1にスラグ生産量を, 転炉・電炉スラグの消費量と 使用内訳を Table 2 に示す10)。転炉スラグは主に土木用と
して利用されている。電炉スラグは道路用路盤材を中心に 利用されている。Table 1を見ると 2001 年度から 2002年度 にかけて，特に転炉スラグの生成量が大きく減少している が，これはスラグのカウント法変更のためであり，従来， 磁選工程で回収した粒鉄および磁選精鉱粉についてはスラ グとして扱ってきたが，2002年度より，回収鉄分として 扱い，スラグ生成量およびスラグ生産量，再使用の数量に 含めないこととしたことによる。そのままでは1997から 2002 年度への経過がわかりにくいので, Table 2 と Fig. 2 に おける数值では，1997年度，2001年度のスラグの生成量 を2002年度のスラグ生成原単位を使用し，修正した值を 記述した。

ダストは発生量原単位から推算すると 2002 年度は年間 約590万トン発生していると推定される ${ }^{11}$ 。高炉ダストは 主に高炉・セメント原料として，電炉ダストは主に電炉原 料・建設資材として再利用される。再利用率は高炉ダスト が $95 \%$ 以上，電炉ダストは約 $40 \%$ となっている。鉄鋼業 で使用された蛍石中のフッ素は，すべてスラグ，ダストに 移行すると仮定した。ダストについては，電気炉ダストの 発生量ならびにその中のフッ素濃度のデータが不明である ため，高炉系·電気炉系の合算としての鉄鋼業への投入量 からスラグへ移行するフッ素を差し引くことで求めた。

污泥は発生量原単位から 2002 年度は年間約 37 万トン発 
1997
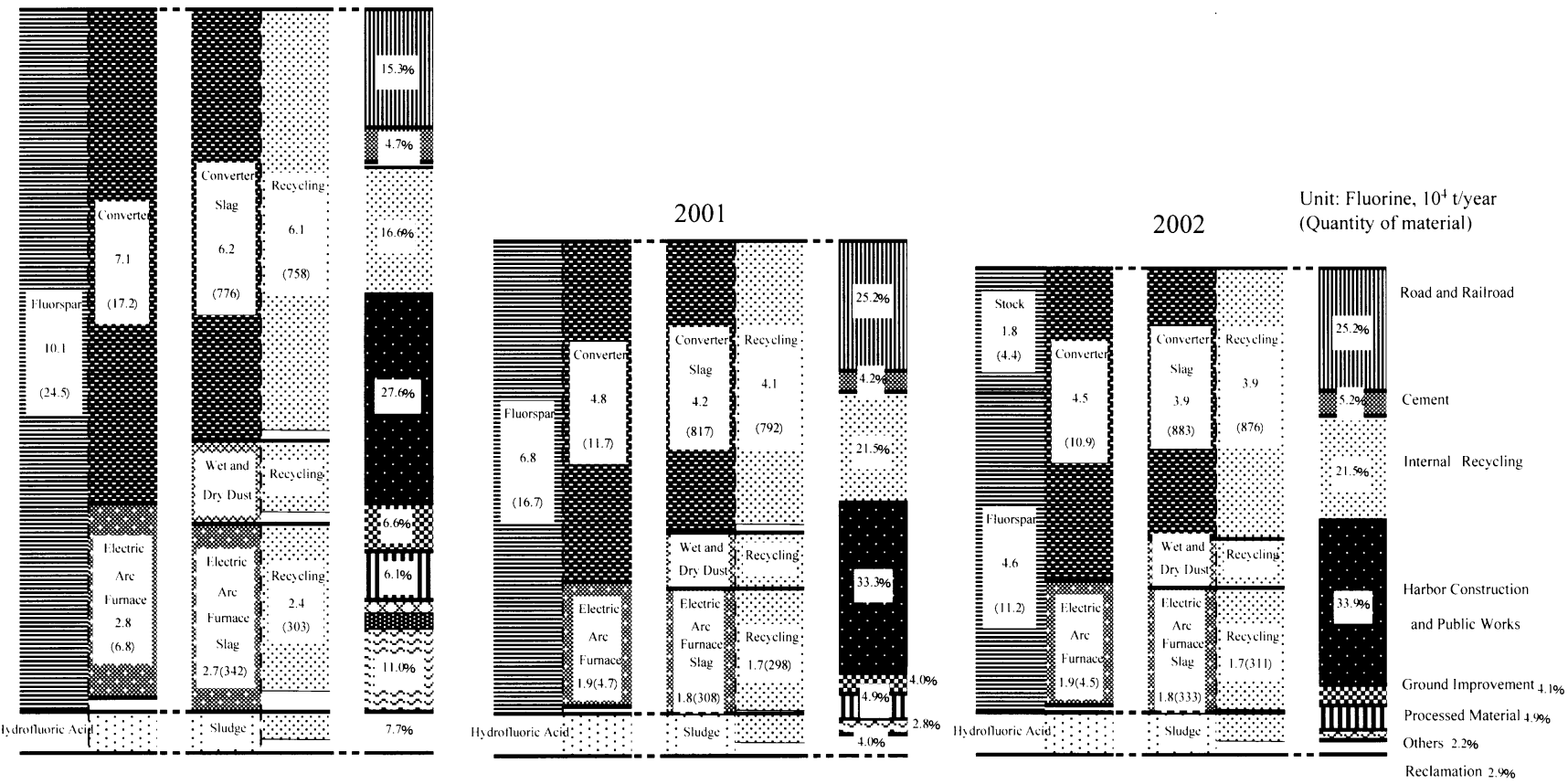

Fig. 2. Material flow diagram of fluorine for slag, dust, and sludge in the iron and steelmaking.

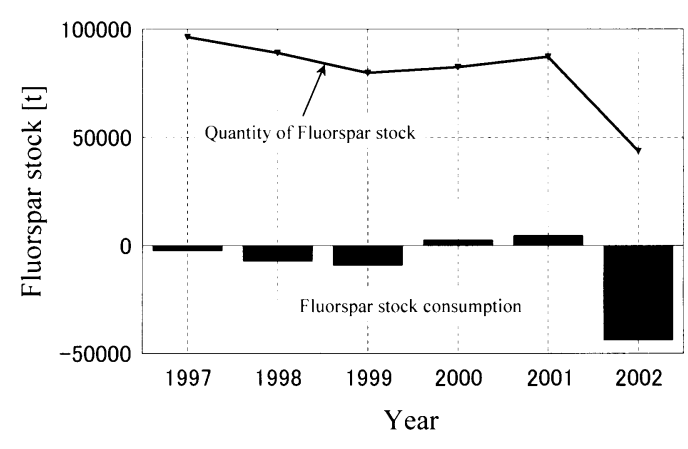

Fig. 3. Quantity of fluorspar stock in the iron and steelmaking.

生していると推定される ${ }^{11)}$ 。再利用率は約 $64 \%$ であり，ス テンレス・クロムメッキ関連の污泥中でフッ素濃度が高く なっている。製鉄所内で発生する污泥中の平均フッ素濃度 は $1.2 \mathrm{mass} \%$ 程度と推定されている ${ }^{4)}$ 。現在ステンレス酸 洗排水のリサイクル ${ }^{12)}$ が検討されているが, 未だ実用化さ れていないので, フッ酸中のフッ素はすべて污泥に含まれ ると仮定した。この結果, 污泥中のフッ素は約4500トン と推定される。污泥は主に焼結原料として再利用される。 以上のデータを元に算出した 1997，2001，2002年の鉄鋼 業におけるフッ素のマテリアルフローを Fig. 2 に示す。鉄 鋼業で消費される蛍石の約 $98 \%$ は転炉 . 電炉用として使 用され，そのうち転炉用は約 $70 \%$, 電気炉用は約 $28 \%$ を占 める。その他のフッ素源として, ステンレス表面処理など に使用されるフッ酸が挙げられる。

マテリアルフローを見ると, 規制強化前の1997年に比 ベ，規制強化後の 2001 年，2002年は蛍石の消費量が約 7.8 万トン，割合にして約 $30 \%$ 削減されている。2001 年と

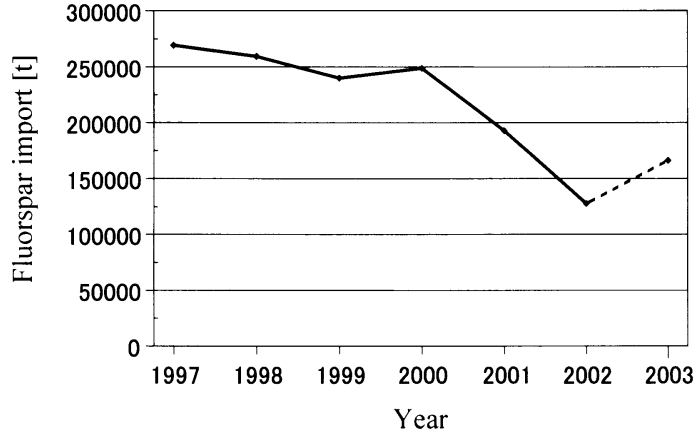

Fig. 4. Import of fluorspar in the iron and steelmaking.

2002年に関しては，前述したように蛍石としての輸入量 はさらに減少しているが，使用量はそれほど低下していな い。この分は在庫量の半分にあたる約 4.4 万トンを使用し たためである。ここで在庫量の経年変化を Fig. 3 に示す ${ }^{13)}$ 在庫量の統計值をプロットしたもの（折れ線グラフ）と， 前年在庫量と当年在庫量との差を在庫消費量として（棒グ ラフ）示している。1997年から2001年までは在庫量の変 化はほぼ 1 万トンの間にあり, 通常約 8 万トンの在庫を確 保してきた。しかしながらフッ素の規制が導入され，普通 鋼の製造には蛍石の使用を抑えるプロセスを導入したこ と，ならびに近年になって主な輸入先であった中国が蛍石 の輸出を制限する傾向が出てきたこともあいまって，2002 年度は在庫の半分である 4.4 万トンを取り崩している。蛍 石の適正在庫量についてはどの位が適性であるかここでは 議論できないが，少なくとも鉄鋼では，約 1 年分弱の在庫 量を確保していることになる。このように鉄鋼業はフッ素 の排水規制が導入され，蛍石の使用を制限しているが，必 
ずしも全面使用禁止にしておらず，特に電気炉では特殊鋼 の需要があるためにその削減量は大きくない。この背景に は，やはり蛍石以上の便利な涬化作用を持つ物質がなく， また多少蛍石からスラグにフッ素が入ってもスラグからの 溶出を抑える技術開発が行われ，厳しい環境基準に対応し ているためと思われる。Fig. 4に鉄鋼業の蛍石受け入れ量 の経年変化を示す ${ }^{13)}$ 。原材料統計の「受入量」の值を引用 した。2003年は 8 月までのデータからの推定值である。こ のグラフから，2001年の規制強化により，鉄鋼業界では 蛍石の購入を控える方針を採ったが，また 2003 年には輸 入量を増加させている。このことは前述のように蛍石を利 用したプロセスでも環境基準を満たす事ができるためと推 定される。

副生物中フッ素の行き先の詳細までは知ることができな いが，再利用は，所内利用であり，所内で循環しているも のと推察される。本論文では，入出力のみを記述している ため, 所内の循環量の内訳に関しての詳細な数値は明らか になっていない。所外へは，セメント，道路，港湾上木用 の路盤材として活用されており，特に港湾土木，道路鉄道 用の利用先が多くなっている。路盤材として使用した場合 の環境基潐を満たす技術開発が未だ完全ではないにしても ほほ確立されたことが鉄鋼における蛍石の使用量に表れて いる。

\section{$3 \cdot 2$ 化学工業におけるフッ素のマテリアルフロー}

化学工業では，工業的に使われるフッ化物のほとんどを， 蛍石に硫酸を作用させて得られるフッ化水素酸を原料とし ている。フッ化水素酸 (HF, 50 mass\%) は2002 年には約 22 万トン生産されており，フッ素換算すると，化学工業で消 費されたほたる石はほとんどがフッ化水素酸製造用であっ たと考えられる。化学工業で生産されるフッ化物の代表例 には，フルオロカーボンやフッ素樹脂が挙げられる。2002 年の化学工業統計年報によれば，フルオロカーボンは約 12 万トン，フッ素樹脂は約 2.2 万トン生産されている。

フルオロカーボンとは, メタン, エタンなどの炭化水素 中の水素を塩素やフッ素で置換した化合物であり, クロロ フルオロカーボン (CFC), 八イドロクロロフルオロカーボ
ン (HCFC)，ハイドロフルオロカーボン (HFC) と組成ごと に区別されている。フルオロカーボンはオゾン層破壊物質 であり，国際的に協調してオゾン層保護対策を推進するた め，「オゾン層の保護のためのウィーン条約」(1985年) 及び「オゾン層を破壊する物質に関するモントリオール議 定書」（1987年）に基づき，オゾン層破壊物質を生産量な どの削減が行われており，先進国では主要なオゾン層破壊 物質（CFCなど）の生産は，1995年末までに全廃されて いる。HCFCも，CFCほどではないがオゾン層破壊能力が あるため，2004年以降生産量を1989年レベルに凍結し， 2019年には全廃となることが決定している ${ }^{14)}$ 。HFCは， 現在生産規制等が進められているオゾン層破壊物質の代替 物質のひとつであり，従来のフルオロカーボンと同様に優 れた物理的，化学的性質を持っている。毒性がないなど安 全性が高く，物性に優れているが，最大の特長はオゾン層 を破壊しないことである ${ }^{15) 。 ~}$

フッ素樹脂は分子中にフッ素を含有する合成高分子の総 称で，高機能性プラスチックである。生産量はプラスチッ ク全体の $0.1 \%$ 以下に過ぎないが，耐熱性，耐薬品性，難 燃性, 低摩擦性, 非粘着性など, 他のプラスチックに比べ 群を抜いた高い機能を持っている。高機能性により徐々に その需要は増加している。種類は, PTFE（ポリテトラフ ルオロエチレン), PFA（パーフルオロアルコキシアルカ ン), ETFE (エチレンテトラフルオロエチレンコポリマー) などが挙げられるが，PTFEはテフロンの名で知られ， もっとも大量に生産されている。その用途は，その高機能 性から, 化学プラント, 半導体産業, 電気電子部品, 自動 車部品, 家庭用調理器具コーティング, 施設園芸用被覆な ど多岐にわたっている ${ }^{16)}$

Fig. 5 に化学工業に打けるフッ素のマテリアルフローを 示す。生産されるフロン, フッ素樹脂は多種に渡り，フッ 酸の使用用途も広範囲に広がっているため，その詳細につ いて知ることは困難であった。ここでは，全フロン中に占 めるフッ素の割合を化学組成から推定した4.17)。フッ素樹 脂中のフッ素は最も大量に生産されているPTFEの化学組 成による推定值である ${ }^{4}$ 。これにより，フロン中のフッ素
1997

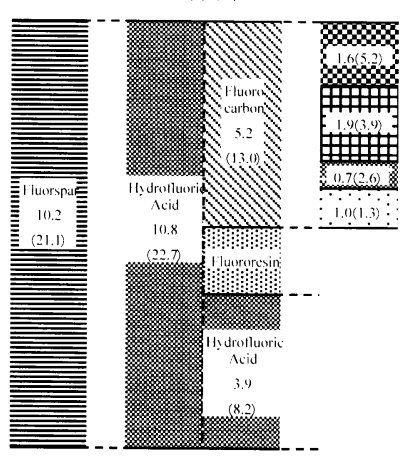

2001
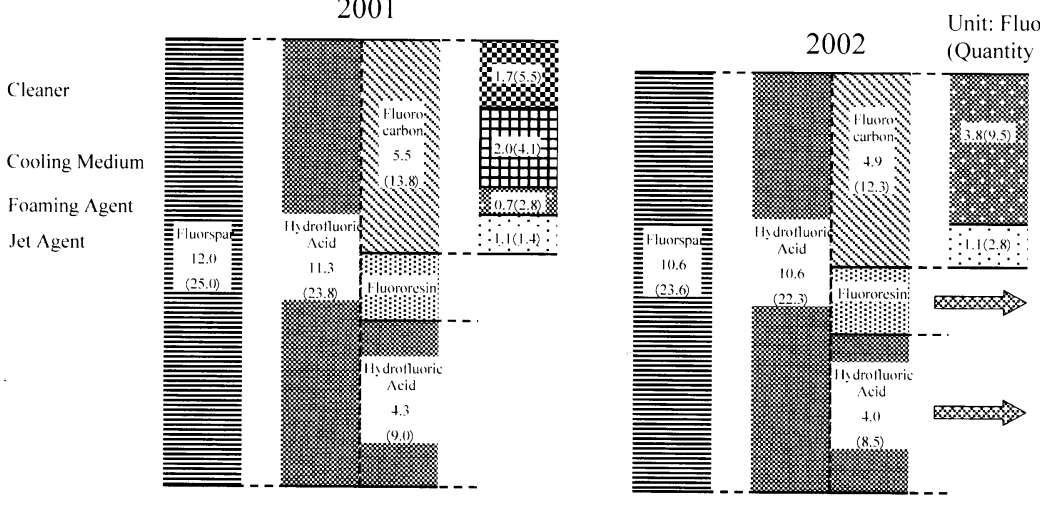

Unit: Fluorine. $10^{+} \mathrm{t} / \mathrm{yea}$

$\mathrm{HCFC}$

Others

Transport units. General units Precision instruments

Material for other fluorides Etching agent for silicon oxide film Acid treatment of stainless steel

Fig. 5. Material flow diagram of fluoride in the chemical industry. 
量は約 5 万トン，フッ素樹脂中のフッ素量は約 2 万トン， フッ酸中のフッ素量は約 4 万トンと推定される。2002年 データより, 化学統計年報の原材料統計が廃止されたため, 蛍石の使用量が調查不能になった。そこで, フッ酸の使用 量から推定した。化学工業は鉄鋼業とは違い, 規制強化前 後で大きな変化は見られず，この傾向は1997年から 2002 年まで大きな変化がない。化学製品の場合は，フッ素化合 物そのものが商品であり，その需要も，フロンを除いて現 状では低下する要素は考えにくいので，フッ素使用量の変 化は起こっていない。先述したように，フッ素樹脂は高機 能プラスチックであるため, 今後需要が増加する可能性を 持っている。フッ酸はステンレス表面処理や半導体洗浄な どに使用され, 今後, 需要増加の可能性を秘めているとい える。フロンは，世界的に規制がなされている物質で，日 本でも規制が強化されていく傾向にあるため，今後は需要 が減少していくものと思われる。現在は，正式に公開され ているフロンに関する具体的なデータが少なく，調査を継 続する必要があると思われる。フロン回収破壊法施行後の 動向が注目される。

\section{4. フッ素排水処理技術と回収フッ素の利用}

フッ素の排水規制が強化されたことにより，原料として のフッ素の使用抑制を行うとともに，排水中に含まれる フッ素の除去に関する技術開発が行われた。その動きを年

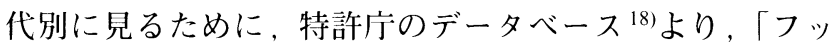
素・排水・処理」のキーワードで検索し，その内容を出願 時の日付を基に，分布を作成した。その結果をFig. 6 に示 す。これを見ると，1998年から2001年まで，それ以前に 比心゙若干多くで特許が提出されているが，意外にも規制強 化前後での目立った変化は見受けられない。このことは， フッ素排水の処理は, 適用技術が原理的に限られており, 本質的にフッ素排水の処理に関して決定的なものがなく， 従来から提案されている方法の改良版が中心であることに 起因しているものと推察される。処理技術のタイプとして は，カルシウム添加による，フッ化カルシウムの除去とい

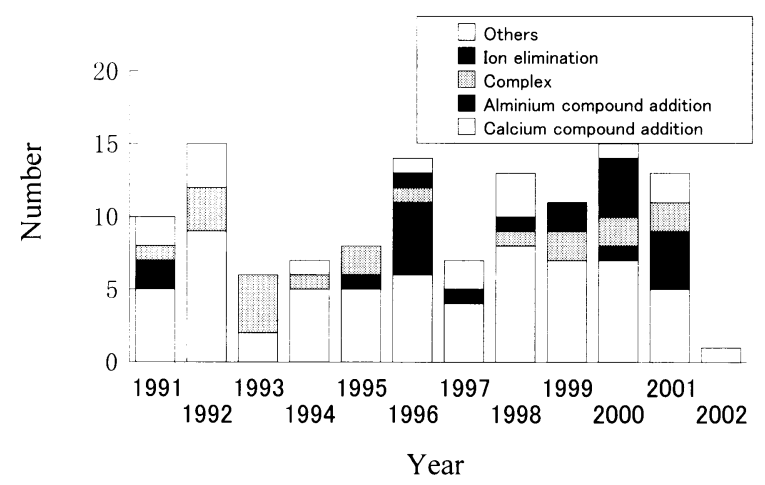

Fig. 6. Number of patent of fluorine wastewater treatment.
う方法の出願件数が最も多い。細かな部分で，プロセスの 違いはあるものの，この方法が最も一般的な方法と思われ る。アルミニウムの添加は, ナトリウムも添加し水晶石を 生成する方法，アルミニウム塩を凝集剤として使用する方 法，フッ素の吸着剂など多種の方法がある。近年，増加し つつある方法としては，イオン交換膜によるイオン除去法 が挙げられる。複合型は，カルシウム添加とアルミニウム 添加を行うものや，リン除去などといっしょに行うプロセ スなどがある。その他にはフッ化アンモニウムとして除去 する方法等も提案されている。その他，フッ素含有アパタ イトの生成により，安定化を行うことも検討されている。

いずれにせよ現在導入されているフッ素排水処理技術は フッ化カルシウムの生成, 沈殿, ろ過法が中心である。こ のことは廃水処理によりフッ化カルシウムが回収できるこ とを意味している。もちろん廃水処理から生成したフッ化 カルシウムには天然には含まれない不純物が含まれ，その まま使用できないことも考えられるが，本論文で示したよ うに鉄鋼業で使用しているフッ化カルシウムの純度はそれ ほど高くない。現在の処理技術で回収されるフッ化カルシ ウムは純度的には十分使用可能と思われる。ただ，通常 フッ化カルシウム沈殿の乾燥物は, 繊維状で見かけ比重が 小さく，フラックスとしてそのままの使用は難しいと考え られる。したがって，他のフラックス成分（主に $\mathrm{CaO} ）$ と 上手く混合し，滓化性のよいフラックスの開発が望まれ る。このことは, 前述したように主な輸入先の中国の蛍石 輸出制限に対するリスク回避にも繋がり，しいては資源生 産性の向上に貢献する。

\section{5. 結言}

1997，2001，2002年の国内フッ素のマテリアルフロー を調査し，日本国内でのフッ素の使用は，フッ素の排水基 準が強化された後, 全体としては減少していることがわ かった。特に鉄鋼業界では, 蛍石の在庫量の減少, 使用量 の減少により，規制強化前に比べ約 $30 \%$ 減少した。化学 工業では, フッ素が商品となっているため, 規制強化後も 顕著な減少は見られない。逆に，フッ素樹脂は，今後需要 伸びが予想されている。化学工業で現象の可能性があるの はフロンの生産量で，これは排水基準の規制強化ではなく， 国際的なオゾン層保護目的によるフロンガス生産の規制に よるものである。排水規制強化については，数多くの特許 が申請されているとおり，排水処理技術を向上させること により対応していると考えられる。

フッ素は使用用途が大変広く, 最終的な行先の詳細を知 ることは今回の調査で十分にはできなかった。これからの 更なる調査特にスラッジにおけるフッ素の含有量の調査が 重要である。

排水処理技術はカルシウム添加によるフッ化カルシウ 
ム，つまり蛍石の除去という方法が最も多いことから，蛍 石のリサイクルという可能性に期待したい。

最後に，今回このようなマテリアルフローを作成するに あたり，多くの公式な統計データを検索し，利用したが， 年々統計データの廃止項目が増えており，統計データが雑 になってきているといわざるを得ない。前述したように， 今後はこのようなトータルな観点から環境を効率的に考察 することが重要となってきており，このようなデータベー スの整備は必要不可欠になってくるものと思われる。

\section{文献}

1 ) A.Noaki, T.Nakamura, S.Kimura and K.Iwata: CAMP-ISIJ, 15 (2002), 777.

2 ) フロンの環境化学と対策技術。化学総説 No. 11, 日本化学会 編，学会出版センター，東宗，(1991), 81 .

3 ) R.Inoue and H. Suito: Tetsu-to-Hagané, 88 (2002), 347.

4 ) E.Shibata, E.Kasai and T.Nakamura: Sozaiken Iho, 55 (1999), 81 .
5 ) A.Shuld: J. National Pure Water Assoc., 5 (1999), 3.

6 ) K.Takahashi: Fluoride, 31 (1998), 61.

7 ) Agency for Toxic Substances and Disease Registry (ATSDR): Toxicological Profile for Fluorides, Hydrogen Fluoide, and Fluorine (F), US. Department of Health\&Human Services, Public Health Service, ATSD/TP-91/17, (1993), 53.

8 ) 茅陽一：環境年表' $98 /$ '99, オ一公社, 東宗, (1997), 138.

9 ) 化学工業年鑑2002, 化学工業日報社, (2002), 406 .

10）鐵鋼スラグ協会：http://www.slg.jp/index.htm

11）鉄鋼業におけるゼロエミッションへの展望，日本鉄鋼協会， 東京, (2003), 4.

12) H.Uesugi, Y.Hara, F.Tanno, T.Nakamura and E.Shibata: Testu-toHagané, 88 (2002), 580.

13）鉄鋼統計年報，経济産業調査会.

14）平成 14 年度オゾン層等の監視結果に関する年次報㑯青，環境 省地球環境局環境保全対策課フロン等対策推進公。 http://www.env.go.jp/press/press.php3?serial=4254

15) 日本フルオロカーボン協会：http://www.jfma.org/

16) 旭硝子ホームページ：http://www.agc.co.jp

17）省エネアラカルト，三重県中小企業情報センター編， 响。 (1999)

18）特許庁特許電子図書館：http://www.ipdl.jpo.go.jp/homepg.ipdl 